\title{
Obituaries
}

\section{Stephen Sebag-Montefiore Doctor and psychotherapist}

Stephen Sebag-Montefiore was the son of Colonel Eric Sebag-Montefiore and Audrey Haldin. His father, nicknamed Colonel Blood for his irrepressibly expletive laden stentorian boom (and for once chasing a fellow officer around the mess with a naked sword), was a landowner, soldier, and Master of Foxhounds. Stephen and his sister Sonia spent [their] first years in India but were brought up in a rare hybrid of Jewish and English traditions.

Born into the so called cousinhood of Jewish banking families, Sebag-Montefiore was a great great nephew of Sir Moses Montefiore, the Italian born Victorian baronet and philanthropist, who was the brother in law and partner of N. M. Rothschild; and great grandson of the banker Sir Joseph Sebag-Montefiore. His maternal grandparents were Sir Herbert and Lady Leon, who lived at Bletchley Park, where he often stayed as a boy.

Sebag-Montefiore typically went his own way. At school he developed blood poisoning from a rugby cut. The operation that saved his life also left him with a leg he could not bend, a weakened heart, and, after a year in hospital, an interest in medicine and love of reading. He never let his limp stop him either dancing or rushing everywhere, and as he crossed roads, taxi drivers would often shout, 'Watch it, governor, or you'll lose the other one!'

After Wellington College and reading medicine at Magdalene College, Cambridge, he qualified as a doctor at the Middlesex Hospital in 1950; interning at the Queen Elizabeth Hospital for Children before starting his own private general practice in Kensington. In his 40s he qualified as a psychotherapist specialising in family therapy. He was able to combine general practice with psychotherapy to become a family doctor who could deal with everything from the common cold to treating depression and marital or family crises. He was an old fashioned sort of doctor who regularly visited patients day or night with his black bag. He treated depression with hypnosis - and compassion - but he was also an innovator, using acupuncture and allergy treatments long before they were generally accepted. He ran his practice from the basement of his Kensington townhouse, where his sons were told that anything they saw in the house was secret and never to be repeated.

Running the family therapy clinic at St Bartholomew's Hospital from 1966 to 1983, he took his MD with a thesis on electroconvulsive therapy in 1975, moved to Harley Street in 1981, and in 1993 was elected president of the hypnosis and psychosomatic medicine section at the Royal Society of Medicine.

Sebag-Montefiore looked after many generations of the same families - and saw famous patients too: Peter Sellers, Dudley Moore, Peter Cook, and many others. But he treated

The obituary was first published in the BMJ on 8 July 2014. BMJ 2014; 349: g4489.

(C) 2014 BMJ Publishing Group Ltd. everyone the same and had no interest whatsoever in being a doctor to society or stars.

He was shy, laconic, and passionate in private life, but dynamic, creative, and original in his practice and always calm, patient, and caring. He was impossible to shock and non-judgemental, usually concluding, whether to patients or his own children, 'Don't worry - that's perfectly normal'. Dudley Moore and Peter Cook did a comic sketch based on him, called 'Perfectly Normal' (or, in other versions of the sketch, 'Perfectly Understandable', another one of his phrases) in which Moore confessed ever more outrageous desires to which Peter Cook, playing Sebag-Montefiore, calmly replied 'Don't worry, that's perfectly normal'.

He married April Jaffe, a doctor's daughter and novelist, at Bevis Marks Synagogue. Happily married for 62 years, they brought up four sons while April helped him run his hectic practice. Sebag-Montefiore loved opera, gardening, and literature. When two of his sons became authors, he helped edit their books, and even diagnosed Simon's subject, Prince Potemkin, as having cyclothymia - and analysed the symptoms of Herod the Great's agonising death from worms bursting out of his swollen belly and scrotum. Even in his last days, he was always available to his family, including 11 grandchildren, to give wise advice that usually concluded: 'Don't worry. That's perfectly normal'.

He donated his body to medical research. He leaves his wife and four sons.

Stephen Eric Sebag-Montefiore (b. 1926; q Cambridge/ Middlesex 1950), died 1 June 2014.

Simon Sebag-Montefiore

doi: 10.1192/pb.bp.114.050179

\section{Dennis Friedman FRCPsych}

Psychiatrist and media commentator who blamed the 2008 economic meltdown on the way in which bankers were parented.

Psychiatrist Dennis Friedman became a sought after media commentator on the relationships of the British Royal Family after writing a series of 'psychobiographies' of the Royals. ${ }^{1-3}$ His real interest, however, was the dynamics of all families - particularly the way early upbringing may affect people's later lives.

His theories were drawn from his lengthy clinical career, first in general practice in the early years of the National Health Service, then as a psychiatrist. Friedman was still in contact with some of his patients - albeit informally - when he died at the age of 90. His recently updated book Inheritance: $A$ Psychological History of the Royal Family ${ }^{1}$ considers the effect of the parenting styles of the country's most prominent family, from Queen Victoria's distant relations with her firstborn son, 